\title{
PENGEMBANGAN MODEL PEMBELAJARAN PRAKARYA DAN KEWIRAUSAHAAN MELAUI UNIT PRODUKSI DI SEKOLAH MENENGAH KEJURUAN
}

\author{
Ayu Tri Wardani ${ }^{1}$ \\ ${ }^{1}$ Teknik Informatika, STIMIK Handayani Makassar \\ ayutriii@handayani.ac.id
}

\begin{abstract}
ABSTRAK
Tujuan penelitian yaitu (1) Mengetahui cara pengembangan model pembelajaran Prakarya dan Kewirausahaan melalui unit produksi di SMK, (2) Menghasilkan perangkat pembelajaran Prakarya dan Kewirausahaan melalui unit produksi di SMK, (3) Menguji tingkat kevalidan, kepraktisan, dan keefektivan model pembelajaran Prakarya dan Kewirausahaan yang dikembangkan untuk digunakan di SMK. Jenis penelitian yang digunakan adalah Research \& Development yang mengacu pada model Borg and Gall yang kemudian disederhanakan dan dimodifikasi sesuai kebutuhan penelitian. Produk pengembangan yang dihasilkan adalah Model Pembelajaran Prakarya dan Kewirausahaan melalui Unit Produksi di SMK beserta buku panduan model, modul pembelajaran, dan Rencana Perangkat Pembelajaran (RPP). Penelitian pengembangan ini dilaksanakan di SMK Muhammadiyah 2 Bontoala Makassar. Hasil penelitian yang diperoleh adalah (1) Model pembelajaran dikembangkan dengan model pengembangan yang diadaptasi dan dimodifikasi dari model Borg and Gall yang terdiri dari 7 tahap, yaitu: (a) Penelitian Terhadap Produk yang Telah Ada, (b) Perancangan, (c) Pengujian Internal, (d) Revisi, (e) Uji Coba (f) Revisi, (g) Kajian Produk Akhir, (2) Perangkat yang dihasilkan yaitu berupa Buku Panduan Model Pembelajaran, Modul Pembelajaran, dan RPP, (3) Model dan perangkat yang dikembangkan telah teruji valid, praktis dan efektif.
\end{abstract}

Kata Kunci: Pengembangan Model Pembelajaran, Prakarya Dan Kewirausahaan, Unit Produksi.

\section{DEVELOPMENT OF ENTREPRENEURSHIP AND ENTREPRENEURS LEARNING MODEL THROUGH PRODUCTION UNITS IN VOCATIONAL MIDDLE SCHOOL}

\begin{abstract}
The research objectives are (1) to know how to develop a craft and entrepreneurship learning model through a production unit at a vocational school, (2) to produce a craft and entrepreneurship learning tool through a production unit at a vocational school, (3) to test the level of validity, practicality, and effectiveness of the craft and entrepreneurship learning model. Entrepreneurship developed for use in SMK. The type of research used is Research \& Development which refers to the Borg and Gall model which is then simplified and modified according to research needs. The resulting development product is the Craft and Entrepreneurship Learning Model through the Production Unit in Vocational High Schools along with model guidebooks, learning modules, and Learning Device Plans (RPP). This development research was carried out at SMK Muhammadiyah 2 Bontoala Makassar. The research results obtained are (1) the learning model was developed with a development model adapted and modified from the Borg and Gall model which consists of 7 stages, namely: (a) Research on Existing Products, (b) Design, (c) Testing Internal, (d) Revision, (e) Trial (f) Revision, ( $g$ ) Final Product Study, (2) The resulting tools are in the form of Learning Model Guidebooks, Learning Modules, and RPP, (3) Models and tools that developed has been tested valid, practical and effective.
\end{abstract}

Keyword: Development of Learning Models, Crafts and Entrepreneurship, Production Units. 


\section{PENDAHULUAN}

Menciptakan SDM Indonesia yang memiliki jiwa kewirausahaan dibutuhkan upaya yang besar dan maksimal, hal ini dapat dilakukan melalui pendidikan sebagai wahana dalam mencerdaskan kehidupan bangsa. Pendidikan nasional berfungsi mengembangkan kemampuan dan membentuk watak serta peradaban bangsa yang bermartabat dalam rangka mencerdaskan kehidupan bangsa, bertujuan untuk berkembangnya potensi peserta didik agar menjadi manusia yang beriman dan bertakwa kepada Tuhan Yang Maha Esa, berakhlak mulia, sehat, berilmu, cakap, kreatif, mandiri, dan menjadi warga negara yang demokratis serta bertanggung jawab[1].

Sekolah Menengah Kejuruan (SMK) sebagai sub sistem pendidikan nasional mempunyai peluang yang cukup besar untuk ikut serta dalam pembangunan SDM yang kreatif, inovatif dan mempunyai daya tahan terhadap perubahan. Pendidikan kejuruan merupakan salah satu jenis pendidikan dalam sistem pendidikan nasional yang terkait dengan perkembangan jenis pekerjaan dan profesi serta sesuai perkembangan teknologi dan kebutuhan masyarakat [2]. SMK mempunyai tujuan agar lulusanya pada akhirnya menjadi SDM yang siap memasuki lapangan kerja dan melanjutkan pendidikan ke jenjang yang lebih tinggi.

Pendidikan kewirausahaan melalui mata pelajaran kewirausahaan yang diberikan di SMK dimana pada kurikulum 2013 telah dipadukan menjadi Prakarya dan Kewirausahaan (PK dan KWU), akan membentuk pola pikir serta paradigma peserta didik yang awalnya adalah lulus sekolah mencari pekerjaan, menjadi lulus sekolah menciptakan lapangan pekerjaan.

Namun demikian, selama ini pembelajaran PK dan KWU di SMK belum mampu menghasilkan peserta didik yang memenuhi kompetensi yang dibutuhkan dunia industri serta ketidakmampuan untuk membuka lapangan kerja sendiri. Pembelajaran PK dan KWU di SMK umumnya masih dilakukan dengan metode ceramah, resitasi, dan membaca buku text. Di samping model pembelajaran kewirausahaan masih text-book oriented, ternyata pelaksanaan pembelajaran dengan menggunakan metode ceramah yang divariasikan dengan metode diskusi belum menekankan pada proses berfikir siswa secara mandiri [3]. Pada umumnya diskusi dilakukan pada kelas yang masih didominasi guru, materi yang dibahas tidak sesuai dengan kontek dan isu-isu moral yang sedang berkembang dalam masyarakat, terutama yang berhubungan dengan kewirausahaan. Ada kecenderungan siswa hanyalah sebagai pendengar penjelasan guru atau hanya sekedar melengkapi Lembar Kerja Siswa [4].

Menempatkan Unit Produksi/Jasa di sekolah sebagai motor penggerak keterlaksanaan proses pembelajaran PK dan KWU merupakan salah satu pengembangan pembelajaran yang akan memberikan pengalaman secara langsung sehingga peserta didik lebih termotivasi dalam proses pembelajaran. Unit Produksi/ Jasa (UP/J) merupakan salah satu kebijakan pemerintah untuk meningkatkan kualitas lulusan SMK di Indonesia. Apabila diamati secara seksama, kegiatan praktik di unit produksi sekolah lebih menekankan pada proses pemebelajaran siswa melalui kegiatan paktek langsung dalam pekerjaan nyata (learning by doing) dalam lingkup kegiatan pembelajaran di sekolah [5]. Manfaat utama dari pendirian UP/J SMK/MAK, yaitu sebagai sumber belajar siswa dan sebagai salah satu sumber pendanaan pendidikan di SMK/MAK [6].

Observasi awal yang telah dilakukan menunjukkan bahwa dari beberapa SMK yang telah dikunjungi hanya SMK Muhammadiyah 2 Bontoala Makassar yang memiliki unit produksi pada program studi TKM. Pengelolaan unit produksi pada program studi TKM di SMK Muhammadiyah 2 Bontoala Makassar telah berjalan baik, sarana yang disediakan sudah cukup mendukung dalam mencapai tujuan UP/J yang telah ditetapkan, walaupun masih banyak hal yang masih perlu dikembangkan lagi, salah satunya adalah menggunakan unit produksi sebagai salah satu sumber belajar khususnya pembelajaran kewirausahaan, mengingat kondisi pembelajaran kewirausahaan di SMK Muhammadiyah 2 Bontoala Makassar masih berlangsung secara teoritis.

Pengintegrasian pembelajaran PK dan KWU dengan kegiatan Unit Produksi di SMK yang dilengkapi dengan penggunaan media interaktif sebagai perangkat pendukung proses pembelajaran, akan menjadi suatu pengembangan dalam pembelajaran kewirausahaan di SMK.

Model pembelajaran prakarya dan kewirausahaan melalui unit produksi/jasa (UP/J) adalah proses pembelajaran yang memotivasi dan melatih keterampilan peserta didik dalam membuat suatu karya atau produk bernilai ekonomis yang dilaksanakan berdasarkan prosedur kerja yang sesungguhnya dan dilakukan pada UP/J sekolah. Model ini dilakukan secara kelompok dimana peserta didik dibagi menjadi kelompok yang akan bekerja sama sebagai tim dari awal kegiatan produksi hingga mennyusun rancana usaha terhadap hasil produknya.

Setiap kegiatan pada model ini harus diimplemantasikan oleh pendidik secara sistemik dimulai dari pembangkitan motivasi siswa, orientasi, 
pelatihan, praktik mandiri, hingga pelaporan hasil produk dalam bentuk presentasi yang dibuat oleh peserta didik.

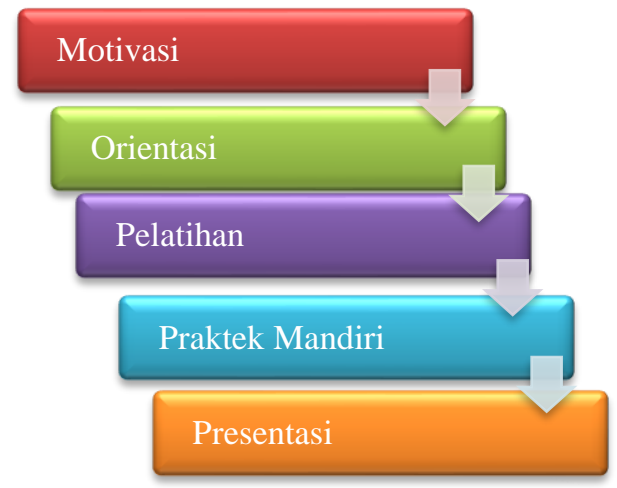

Gambar 1. Model Pembelajaran Melalui UP

\section{METODE PENELITIAN}

Jenis penelitian yang digunakan dalam penelitian ini adalah Penelitian Pengembangan (Research and Development/ R\&D). Dalam penelitian ini model pengembangan yang digunakan adalah model Borg and Gall, yang kemudian disederhanakan dan dimodifikasi sesuai kebutuhan penelitian yang terdiri dari 7 tahap pengembangan yang terbagi menjadi dua bagian, yaitu research (penelitian) yaitu (1) melakukan penelitan terhadap produk yang telah ada, yang dilakukan dengan cara mengadakan penelitan lapangan dan studi literatur terkait penelitian yang dilakukan, dan yang kedua adalah development (pengembangan) yang terdiri dari (2) perancangan, (3) pengujian internal (validasi), (4) revisi, (5) uji coba, (6) revisi, (7) Kajian Produk Akhir.

\section{A. Tempat dan Waktu Penelitian}

Penelitian ini dilaksanakan pada program studi Teknik Komputer dan Multimedia (TKM), SMK Muhammadiyah 2 Bontoala Makassar, pada tahun ajaran 2019-2020.

\section{B. Subjek Pengembangan}

Pada uji coba produk yang menjadi subjek uji coba adalah guru mata pelajaran kewirausahaan dan 30 peserta didik kelas XI TKM 1 SMK Muhammadiyah 2 Bontoala Makassar, tahun ajaran 2019-2020.

\section{Prosedur Pengembangan}

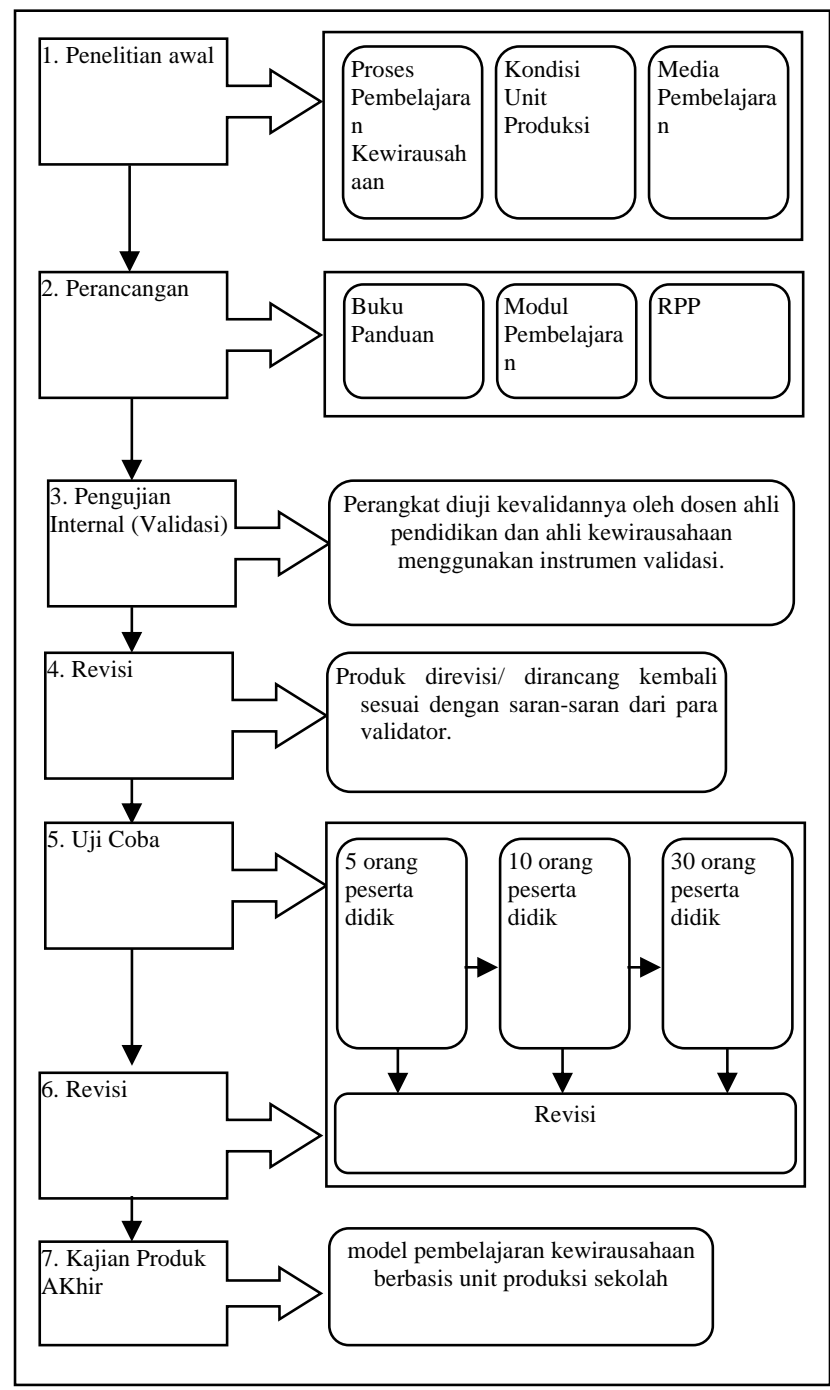

Gambar 2. Langkah-langkah dan Kompenen Penelitian (Modifikasi dari model Borg and Gall)

\section{Teknik Analisis Data}

Analisis data pada penelitian ini adalah menggunakan teknik deskriptif persentase. Data-data yang dianalisis bertujuan untuk mengetahui tingkat kevalidan, kepraktisan dan keefektifan pengembagan produk yang dibuat.

\section{Analisis Data Kevalidan}

Analisis data kevalidan dilakukan oleh dua ahli pendidikan untuk menilai kalayakan model pembelajaran yang dikembangkan. Validator model akan mengisi angket dengan memberi skor sesuai rubrik validasi (skor tertinggi $=4$ dan skor terendah=1).

\section{Analisis Data Kepraktisan}

Analisis data kepraktisan diperoleh melalui tanggapan peserta didik dan pendidik terhadap model inovasi pembelajaran PK dan KWU melalui UP/J yang telah dikembangkan dengan mengisi angket. Data dari analisis tanggapan peserta didik serta 
pendidik akan dianalisis menggunakan teknik deskriptif persentase menggunakan rumus sebagai berikut [7]:

$$
\text { Persentase }=\frac{\sum x}{\text { SMI }} \times 100 \%
$$

Keterangan :

$\sum \mathrm{x} \quad=$ jumlah skor

SMI = Skor Maksimal Ideal

Rentang persentase dan criteria kevalidan dan kepraktisan inovasi pembelajaran PK dan KWU melalui UP/J disajikan pada Tabel 1 [8].

TABEL 1. RENTANG PERSENTASE DAN KRITERIA KUALITATIF PRODUK

\begin{tabular}{cc}
\hline Rentang persentase & Kriteria kualitatif \\
\hline $85,01 \%-100 \%$ & Sangat valid \\
$70,01 \%-85 \%$ & Cukup valid \\
$50,01 \%-70,00 \%$ & Kurang valid \\
$01,00 \%-50,00 \%$ & Tidak valid \\
\hline
\end{tabular}

\section{Analisi Data Keefektifan}

Analisis data keefektifan dilihat dari hasil tes peserta didik kelas XI TKM SMK Muhammadiyah 2 Bontoala Makassar tahun ajaran 2015/2016. Model pembelajaran PK dan KWU melalui UP/J dikatakan efektif apabila $80 \%$ nilai evaluasi/ tes peserta didik mencapai KKM [9]. Standar KKM yang digunakan berdasarkan standar KKM yang telah ditetapkan di SMK Muhammadiyah 2 Bontoala Makassar.

\section{HASIL DAN PEMBAHASAN}

\section{A. Hasil Penelitian}

Penelitian dan pengembangan ini menghasilkan model pembelajaran melalui unit produksi yang pada dasarnya merupakan proses pembelajaran yang memotivasi dan melatih keterampilan peserta didik dalam membuat suatu karya atau produk bernilai ekonomis yang dilaksanakan berdasarkan prosedur kerja yang sesungguhnya dan dilakukan pada UP/J sekolah.

TABEL 2. TAHAPAN MODEL PEMBELAJARAN PRAKARYA DAN KEWIRAUSAHAANMELALUI UNIT PRODUKSI

\begin{tabular}{ccl}
\hline No. & Tahap & \multicolumn{1}{c}{ Deskripsi } \\
\hline 1 & Motivasi & Usaha memotivasi peserta didik \\
& & dalam hal ini mencakup proses \\
& membimbing peserta didik \\
& dalam membangun semangat \\
& dan keaktifan pada diri peserta \\
& didik sehingga dia benar-benar \\
& bersedia untuk belajar dan \\
& proses yang menyebabkan \\
& perhatian pelajar tertumpu \\
& kepada satu arah atau tujuan \\
\hline
\end{tabular}

pada satu masa, yaitu tujuan pembelajaran

2 Orientasi Tujuan utama tahap orientasi ini adalah menyiapkan peserta didik untuk ketahap pembelajaran selanjutnya, yaitu tahap pelatihan

3 Pelatihan Memberikan contoh yang dan benar, baik menyangkut langkalangkah kerja, cara penggunaan alat, maupun mengerjakan proses produksi sehingga peserta didik memahami langkah-lankah kerja dan tahu apa yang harus dilakukannya

4 Peaktek Merangsang dan membangun Mandiri kreatifitas peserta didik, memastikan peningkatan daya ingat dan keterampilan peserta didik, serta meningkatkan kelancaran peserta didik dalam menyelesaikan permasalahan

5 Presentasi Tahap dimana peserta didik mebuatkan laporan atas hasil praktik mandiri yang telah dikerjakan

Pengembangan model pembelajaran ini meliputi penyusunan buku panduan model pembelajaran, modul pembelajaran prakarya dan kewirausahaan, dan RPP.

\section{Validitas}

Hasil uji kevalidan berdasarkan penilaian dari kedua validator terhadap buku panduan model yang dihasilkan memperoleh persentase yaitu 95\% dengan kategori sangat valid, sehingga buku panduan ini layak untuk uji coba lapangan. Hasil pengolahan dapat dilihat pada Tabel 3 .

TABEL 3. REKAPITULASI HASIL VALIDASI BUKU PANDUAN MODEL PEMBELAJARAN

\begin{tabular}{clcc}
\hline No & Aspek & Persentase $(\%)$ & Kategori \\
\hline 1 & Format & 100 & Sangat Valid \\
2 & Isi & 88 & Sangat Valid \\
3 & Bahasa & 96 & Sangat Valid \\
\hline Persentase & $\mathbf{9 5}$ & Sangat Valid \\
Kevalidan $(\%)$ & & \\
\hline
\end{tabular}

Hasil uji kevalidan berdasarkan penilaian dari kedua validator terhadap modul pembelajaran yang dihasilkan memperoleh persentase yaitu $89 \%$ kategori sangat valid. Hasil pengolahan dapat dilihat pada gambar berikut. 
TABEL 4. REKAPITULASI HASIL VALIDASI MODUL PEMBELAJARAN

\begin{tabular}{clcl}
\hline No & Aspek & Persentsase $(\%)$ & Kategori \\
\hline 1 & Tampilan & 89 & Sangat Valid \\
2 & Isi & 98 & Sangat Valid \\
3 & Bahasa & 79 & Cukup Valid \\
\hline $\begin{array}{l}\text { Persentase } \\
\text { Kevalidan }(\%)\end{array}$ & $\mathbf{8 9}$ & Sangat Valid \\
\hline
\end{tabular}

Hasil uji kevalidan berdasarkan penilaian dari kedua validator terhadap Rencana Pelaksanaan Pembelajaran (RPP) yang dihasilkan memperoleh persentase yaitu $92 \%$ kategori sangat valid. Hasil pengolahan dapat dilihat pada gambar berikut.

\begin{tabular}{|c|c|c|c|}
\hline No & Aspek & $\begin{array}{c}\text { Persentase } \\
(\%)\end{array}$ & Kategori \\
\hline 1 & Identitas RPP & 96 & $\begin{array}{c}\text { Sangat } \\
\text { Valid }\end{array}$ \\
\hline 2 & KD dan Indikator & 92 & $\begin{array}{c}\text { Sangat } \\
\text { Valid }\end{array}$ \\
\hline 3 & Rumusan Tujuan & 96 & $\begin{array}{c}\text { Sangat } \\
\text { Valid }\end{array}$ \\
\hline 4 & Materi & 100 & $\begin{array}{c}\text { Sangat } \\
\text { Valid }\end{array}$ \\
\hline 5 & Metode & 81 & $\begin{array}{c}\text { Cukup } \\
\text { Valid }\end{array}$ \\
\hline 6 & $\begin{array}{l}\text { Alat, Media dan } \\
\text { Bahan Ajar }\end{array}$ & 91 & $\begin{array}{c}\text { Sangat } \\
\text { Valid }\end{array}$ \\
\hline 7 & $\begin{array}{l}\text { Langkah } \\
\text { Pembelajaran }\end{array}$ & 91 & $\begin{array}{l}\text { Sangat } \\
\text { Valid }\end{array}$ \\
\hline 8 & Penilaian & 96 & $\begin{array}{c}\text { Sangat } \\
\text { Valid }\end{array}$ \\
\hline 9 & Bahasa & 88 & $\begin{array}{c}\text { Sangat } \\
\text { Valid }\end{array}$ \\
\hline \multicolumn{2}{|c|}{$\begin{array}{l}\text { Persentase Kevalidan } \\
(\%)\end{array}$} & 92 & $\begin{array}{c}\text { Sangat } \\
\text { Valid }\end{array}$ \\
\hline
\end{tabular}

\section{Kepraktisan}

a. Respon Peserta Didik

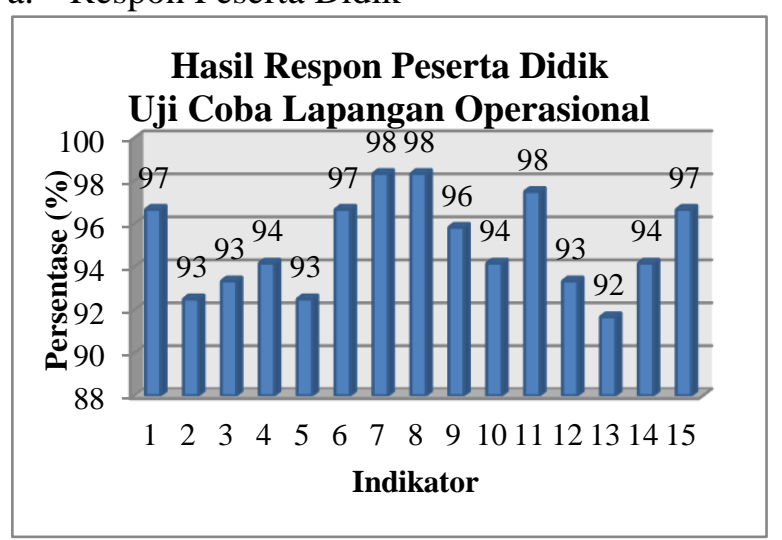

Gambar 3. Diagram Respon Peserta Didik Uji Coba Lapangan Operasional
Berdasarkan hasil respon peserta didik uji coba lapangan operasional diperoleh data bahwa model pembelajaran yang di kembangkan berada pada kategori sangat praktis di tinjau dari beberapa indikator penilaian yaitu $95 \%$.

b. Respon Pendidik

Hasil respon pendidik uji coba lapangan operasional ini diperoleh data bahwa model pembelajaran yang di kembangkan berada pada kategori sangat praktis di tinjau dari beberapa indikator penilaian yaitu $95,00 \%$.

\section{Keefektivan}

a. Aktivitas Peserta Didik

Hasil pengamatan aktivitas peserta didik diperoleh dengan menggunakan lembar observasi. Pengamatan dilakukan oleh dua orang pengamat. Pengamatan dilakukan terhadap 35 peserta didik. Menurut kedua pengamat model pembelajaran yang di kembangkan berada pada kategori sangat efektif di tinjau dari beberapa indikator penilaian yaitu $88 \%$.

Berdasarkan hasil aktivitas peserta didik terhadap model pembelajaran melalui unit produksi diketahui juga bahwa aktivitas peserta didik trerus meningkat tiap pertemuan, datanya dapat dilihat pada Gambar berikut.

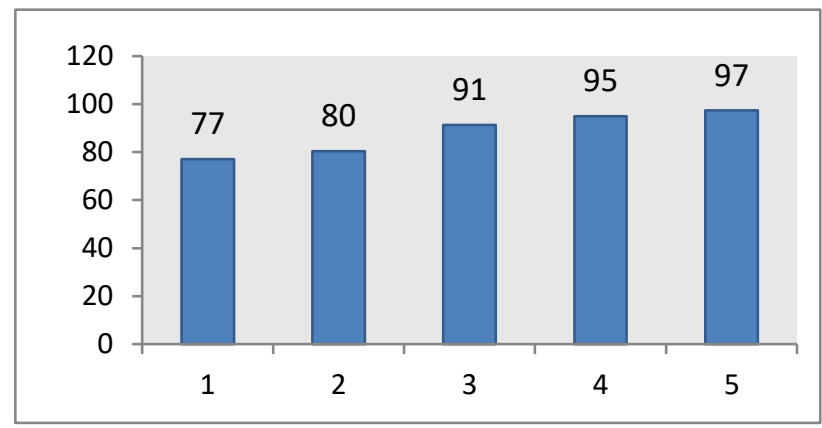

Gambar 4. Diagram Frekuensi Aktivitas Peserta Didik Tiap Pertemuan

b. Aktivitas Pendidik

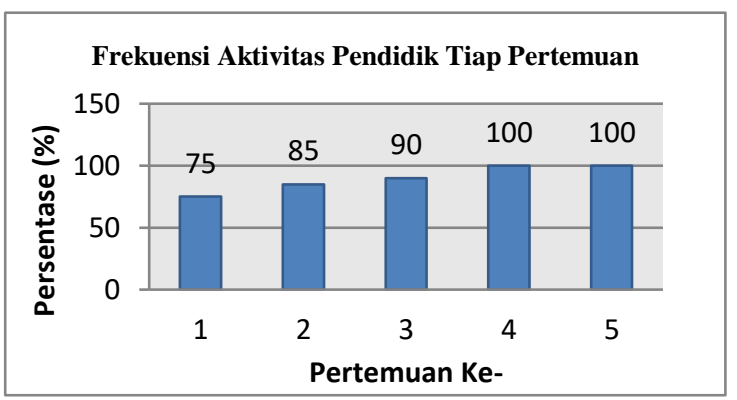

Gambar 5. Diagram Frekuensi Aktivitas Pendidik Tiap Pertemuan

Kegiatan atau aktivitas pendidik selama kegiatan belajar mengajar berlangsung diamati dan dinilai dengan menggunakan lembar pengamatan yang telah 
disusun. Pada pengamatan ini, jumlah aspek yang diamati sebanyak 10 aspek. Menurut dari kedua pengamat model pembelajaran yang di kembangkan berada pada kategori sangat efektif di tinjau dari beberapa indikator penilaian yaitu $90 \%$.

Berdasarkan hasil observasi aktivitas pendidik terhadap model pembelajaran melalui unit produksi diketahui juga bahwa aktivitas pendidik trerus meningkat tiap pertemuan, datanya dapat dilihat pada Gambar 6 .

\section{c. Tes Hasil Belajar}

Untuk mengukur hasil belajar peserta didik maka akhir pembelajaran dilakukan penilaian atau evaluasi tertulis menggunakan soal pilihan ganda dengan soal yang diberikan berjumlah 20 butir soal.

TABEL 6. PERSENTASE TES HASIL BALAJAR PESERTA DIDIK

\begin{tabular}{cc}
\hline Jumlah Peserta Didik Lulus & 28 \\
\hline Persentase Kelulusan (\%) & 93 \\
\hline
\end{tabular}

Kesimpulan dari hasil tes belajar peserta didik yaitu persentase tes hasil belajar peserta didik yaitu $93 \%$ yang berarti persentase kelulusan tes hasil belajar peserta didik telah memenuhi KKM yaitu $80 \%$, yang artinya model pembelajaran PK dan KWU melalui UP/J efektif dalam meningkatkan hasil belajar peserta didik di SMK Muhammadiyah 2 Bontoala Makassar.

\section{B. PEMBAHASAN}

Rancangan penelitian dan pengembangan pada penelitian ini mengacu pada model Borg and Gall yang kemudian disederhanakan dan dimodifikasi sesuai kebutuhan penelitian. Penelitian ini terbagi menjadi dua bagian, yaitu research (penelitian) yaitu melakukan penelitan terhadap produk yang telah ada, yang dilakukan dengan cara mengadakan penelitan lapangan dan studi literatur terkait penelitian yang dilakukan, dan yang kedua adalah development (pengembangan) yang terdiri dari perancangan, pengujian internal (validasi), revisi, uji coba terbatas, revisi, uji coba lapangan, revisi, uji coba lapangan operasional hingga menghasilkan sebuah produk.

\section{A. Uji Kevalidan}

Dilakukan pada tahap pengujian internal oleh dua validator ahli pendidikan. Kesimpulan dari kedua validator terhadap buku panduan model yang dikembangkan memperoleh persentase yaitu 95\% kategori sangat valid ditinjau dari seluruh aspek penilaian. Kesimpulan dari kedua validator terhadap modul pembelajaran yang dikembangkan memperoleh persentase yaitu $89 \%$ berada pada kategori sangat valid ditinjau dari seluruh aspek penilaian. Kesimpulan dari kedua validator terhadap RPP yang dikembangkan memperoleh persentase yaitu $92 \%$ berada pada kategori sangat valid ditinjau dari seluruh aspek penilaian.

\section{B. Uji Kepraktisan}

Dilakukan pada tahap uji coba lapangan operasional dengan menggunakan instrumen respon peserta didik dan instrumen respon pendidik. Berdasarkan respon peserta didik diperoleh kesimpulan bahwa model pembelajaran yang di kembangkan berada pada kategori sangat praktis di tinjau dari beberapa indikator penilaian hasil respon peserta didik yaitu 95\%. Dan berdasrkan respon pendidik juga diperoleh kesimpulan bahwa model pembelajaran yang di kembangkan berada pada kategori sangat praktis di tinjau dari beberapa indikator penilaian hasil respon pendidik yaitu $95, \%$.

\section{SIMPULAN}

Berdasarkan hasil penelitian dan pengembangan dapat disimpulkan beberapa hal sebagai berikut:

1. Model pembelajaran dikembangkan dengan model pengembangan yang diadaptasi dan dimodifikasi dari model Borg and Gall yang terdiri dari 7 tahap, yaitu: (1) Penelitian Terhadap Produk yang Telah Ada, (2) Perancangan, (3) Pengujian Internal, (4) Revisi, (5) Uji Coba, (6) Revisi, (7) Kajian Produk Akhir.

2. Perangkat yang dihasilkan yaitu berupa Buku Panduan Model Pembelajaran, Modul Pembelajaran, dan RPP.

3. Model dan perangkat yang dikembangkan telah teruji valid, praktis dan efektif.

\section{DAFTAR PUSTAKA}

[1] D. P. Nasional, "Undang-undang republik Indonesia nomor 20 tahun 2003 tentang sistem pendidikan nasional," Language, vol. 188, p. $22 \mathrm{~cm}, 2003$.

[2] Darmawan, Strategi Pembelajaran Kejuruan. Makassar: Badan Penerbit UNM, 2008.

[3] E. Mulyani, "Strategi menumbuhkan sikap dan perilaku wirausaha melalui pembelajaran kooperatif yang berwawasan kewirausahaan," Jurnal Ekonomi dan Pendidikan, vol. 6, no. 2, 2009.

[4] A. Hakim, "Model pengembangan kewirausahaan sekolah menengah kejuruan (SMK) dalam menciptakan kemandirian sekolah," Jurnal, vol. 4, no. 1, 2010. 
[5] Z. Z. Firdaus, "Pengaruh unit produksi, pengalaman prakerin dan dukungan keluarga terhadap kesiapan kerja siswa SMK," Jurnal pendidikan vokasi, vol. 2, no. 3, 2012.

[6] Dikmenjur, Pedoman Pelaksanaan Unit Produksi. Jakarta: Dikmenjur, 2007.

[7] I. M. Tegeh, I. N. Jampel, and K. Pudjawan, "Model penelitian pengembangan," Yogyakarta: Graha Ilmu, 2014.

[8] S. Akbar, Instrumen perangkat pembelajaran. Bandung: PT Remaja Rosdakarya, 2013.

[9] T. N. Sari, "Analisis kualitas dan pengembangan sistem informasi akademik berbasis web menggunakan standard iso 9126," JIKO (Jurnal Informatika dan Komputer), vol. 1, no. 1, 2016. 